\title{
ANALYSIS OF PATIENT SAFETY MANAGEMENT IN THE IN-PATIENT ROOM AT DELI HOSPITAL, MEDAN, NORTH SUMATERA
}

\author{
Tona Bontor Melkisedek Sinaga'), Zulfendri²), Juanita ${ }^{2)}$ \\ 1)Masters Program in Public Health, Universitas Sumatera Utara \\ 2)Faculty of Public Health, Universitas Sumatera Utara
}

\begin{abstract}
Background: Patient safety management means to reduce unnecessary risks and adverse events to the minimum possible level while providing health care. The application of patient safety management had not been maximal in some hospitals. It can cause health problems for patients and health workers. This study aimed to analyze the patient safety management in the in-patient room at Deli Hospital, Medan, North Sumatera.

Subjects and Method: This was a qualitative study conducted in February to July 2018. The three informants were consisted of the head of quality improvement and patient safety, the patient safety team, and the nursing committee at Deli Hospital, Medan, North Sumatera. The data were collected by in-depth interview and observation. The data were analyzed using data reduction, data presentation, and conclusion.

Results: The role of hospital organization in implementing management patient safety in the in-patient care had not been maximized. The efforts of increasing the commitment of health workers, working environment condition, facility, implementation of standard operating procedure (SOP), and implementing Situation, Background, Assessment, and Recommendation (SBAR), and implementing sanction, had not been maximize. Communication was not effective. The ability of health workers to perform patient safety had not been maximal as seen from the understanding of a poor safety system. Adverse event report was still of manual type. Number of fall accidents in 2018 was 2 cases.
\end{abstract}

Conclusion: Patient safety management in the in-patient care has not been maximized. Patient safety management can be improved by implementing SOP, SBAR, and its sanctions.

Keywords: management of patient safety, quality of service

\section{Correspondence:}

Tona Bontor Melkisedek Sinaga. Masters Program in Public Health, Universitas Sumatera Utara. Jl. Universitas No 21, Medan 20155, Medan Baru, North Sumatera. Email: tona.sinaga@yahoo.com. Mobile: 081265171221. 